\title{
A Second Pair of Trumpeter Swans Nesting in Saskatchewan
}

by Fred W. Lahrman, Sask. Museum of Natural History

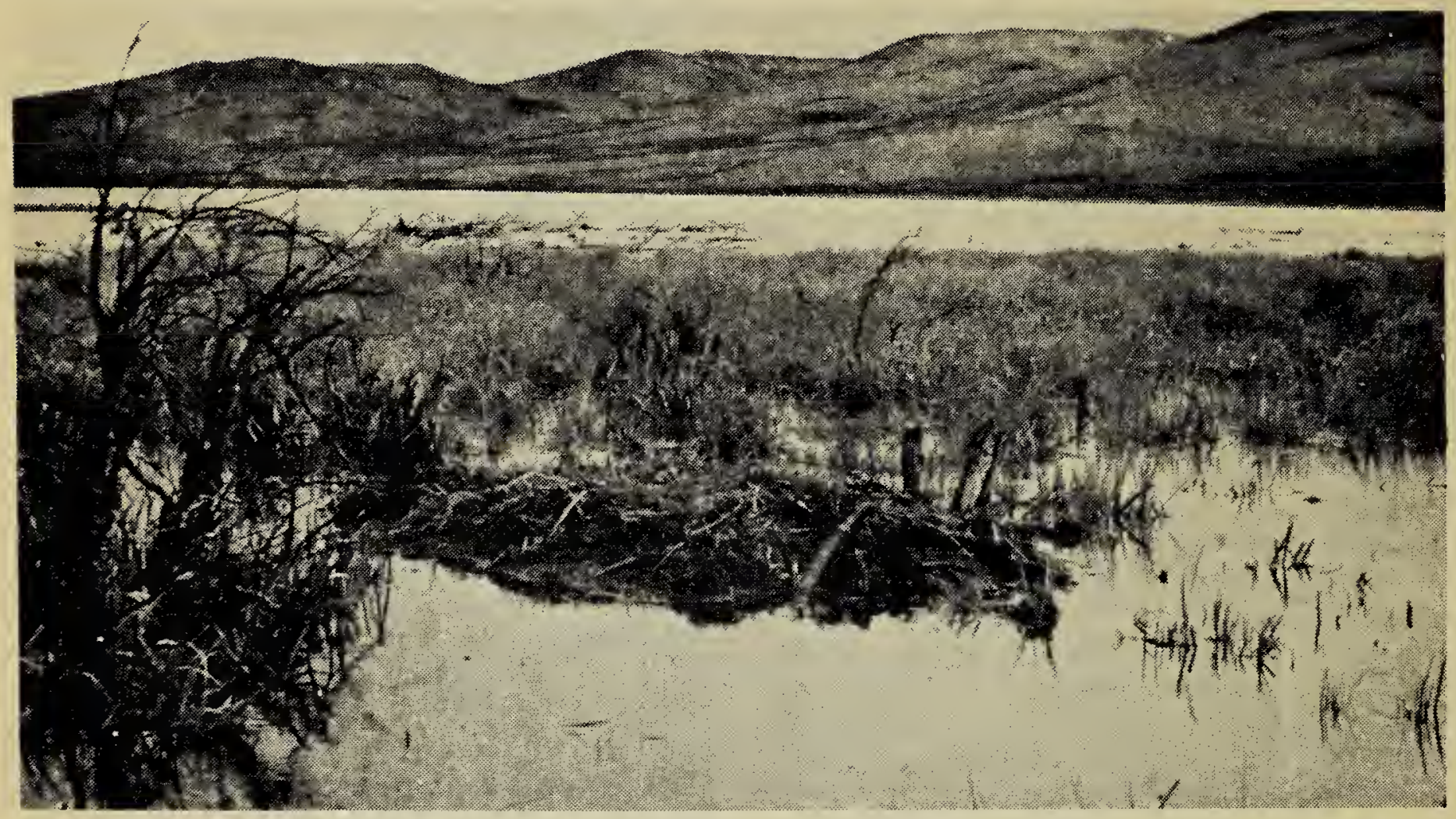

Photo by F. W. Lahrman. S.M.N.H.

Nest of Trumpeter Swans at Adams Lake, May 18, 1960.

On May 18, 1960, F. G. Bard and I checked the nest of a pair of Trumpeter Swans (Cygnus buccinator) on Adams Lake in the Cypress Hills. A pair of Trumpeters has apparently nested annually in this area since the first S.M.N.H. nesting record in 1953 (Blue Jay, 11(4):26-27). In 1957 an additional adult was recorded for the first time with the breeding pair (Blue Jay, 15:138-139).

The huge nest, approximately six feet in diameter, was in shallow water approximately 30 yards from shore and well concealed by marsh vegetation. There were only three eggs in the nest, so evidently the clutch was not complete. The adult birds were very wary and vanished from sight as soon as we appeared, even though we were still over half a mile away. After photographing the nest and eggs we made a hurried retreat because the day was cold, with rain and snow, and we did not want to risk chilling the eggs.

On August 18 we again visited the swans on Adams Lake. This time they had three gray downy young about the size of small geese. There were two adult non-breeding swans on the lake as well. The Conservation
Officer at the Cypress Hills Park reported checking the nest before hatching and there were then seven eggs. It is not known whether the other four eggs were hatched or not, or why the swans had only three young.

Meanwhile David Munro, Chief Ornithologist, Canadian Wildlife Service, reported a pair of swans with four young in the Belanger Creek area, Cypress Hills Park. On September 2, Mr. Bard and I checked the pair on Belanger Creek. We caught a glimpse of the adults before they hid in the rushes, and although no young were seen we believed that the secretive behaviour of the adults indicated they had young hidden near by. The total number of swans observed were seven on Adams Lake and two on Belanger Creek.

Mr. Munro's report of the breeding pair on Belanger Creek was very good news as this is the first time that a second pair of Trumpeters has been known to rest in Saskatchewan and indicates an increase in the small flock residing in the Cypress Hills.

A pair of Trumpeter Swans nesting in the Cypress Hills in Alberta was reported in the Canadian Field- 
Naturalist in 1951 by Robert Lister. Lister had noted a pair without young in 1948 but accompanied by cygnets in 1949 and 1950. This is the only recond for the Cypress Hills given by Winston E. Blanko (1960. The Trumpeter Swan, its history, habits and population in the United Sitates. U.S. Fish and Wildlife Service.) It should be noted, of course, that Banko's study deals primarily with the United States population and' therefore only in a general way with Canada. A comparable study of the Trumpeter has been undertaken by the Canadian Wildlife Service, with investigations being conducted chiefly in British Columbia and Alberta by Ronald H. Mackiay, wildlife biologist.

EDITOR'S NOTE: A pair with one young seen October 4, 1960, by Mrs. Percy Drury on a small lake by the Cypress Hills Park, may have been the pair reported by Munro.

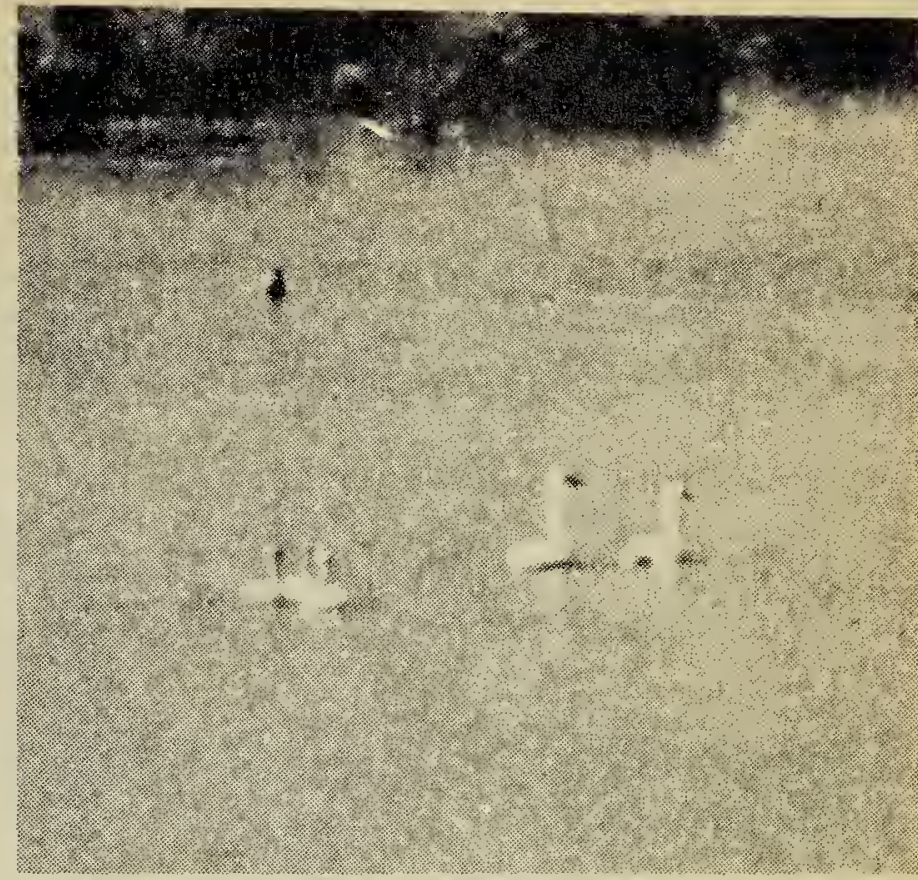

Photo by F. W. Lahrman. S.M.N.H. Trumpeter family on Adams Lake, August 18, 1960.

\title{
My Neighbours the Martins
}

\author{
by Elwin Baines, Tisdale
}

When Mr. and Mrs. E. W. Van Blaricom retired to Kelowna and I moved into their Tisdale home Mr. Van explained to me that the Martin house was included in the deal. However, no Purple.Martins had used the house up to that date, and they came to me in the following spring only because they found their former home in a neighbour's backyard occupied by a family of red squirrels. At the time Tree Swallows and House Sparrows were fighting for possession of my Martin house and the battle had reached a sitalemaite. At this opportune moment the Martins arrived to take over. Their tenantship of the house has not been i. doubt since, and they have raised broods in 1958, 1959 and 1960.

The Martins have proved themselves to be the most desirable neighbours. They chit chat over the clothes line on Monday mornings or they may have a few remarks for me when I drive up with the car or truck. They are extremely tidy and no refuse is ever seen around their house. Now that they are definitely settled nothing disturbs them, and half a dozen strangers can drop in unexpectedly without the Martins objecting.

I can now predict almost to the hour .when the Martins will return from the south each spring. For the past two years, Papa Martin has arrived here on May 8. For 10 days he appears alone and disconsolate. Then, promptly on May 18, Mama Martin is sitting on my telephone wire beside papa. They take possession immediately but do not lay eggs until well into June. Both birds carry in green leaves as soon as eggs are laid. Young hatch early in July. Both parents carry insects, small at first but as soon as the young develop many of those large blue dragonflies are eaten whole, wings and all.

The young do not take practice flights but fly like mature birds the first time out. They only return to the Martin house once or twice and leave the site almosit at once. It appears that Martins take more than one year to develop as there are always some immature birds around that look like last year's young.

What man could duplicate the feat of the Martins? Flying alone with nothing but a pair of strong wings and an unerring instinct the Martins set out from their southern retreat and land at a little white house on the eastern edge of Tisdale almosit to the hour each year. 